\title{
ЗА КОНГРЕСА ПО ПАЛИАТИВНИ ГРИЖИ НА ПАПСКАТА АКАДЕМИЯ ЗА ЖИВОТ
}

В периода 28.02 - 2.03.2018 в Рим се състоя Конгрес по палиативни грижи, организиран от Папската академия за Живот, специализирана научна организация, изследваща основните проблеми на биомедицината и правото във връзка с християнския морал и католическата морална теология. Конгресът беше под надслов „Палиативни грижи навсякъде за всеки“" и събра 380 учени от 38 страни. България беше представена от проф. д-р Силвия Александрова-Янкуловска. Поради изключителната си актуалност и подбор на докладчици програмата беше излъчвана на живо в Youtube, където и към настоящия момент са достъпни докладите от конференцията: https://www.youtube.com/channel/UCcoTSMAX1 vLc47z5z7yPO6g.

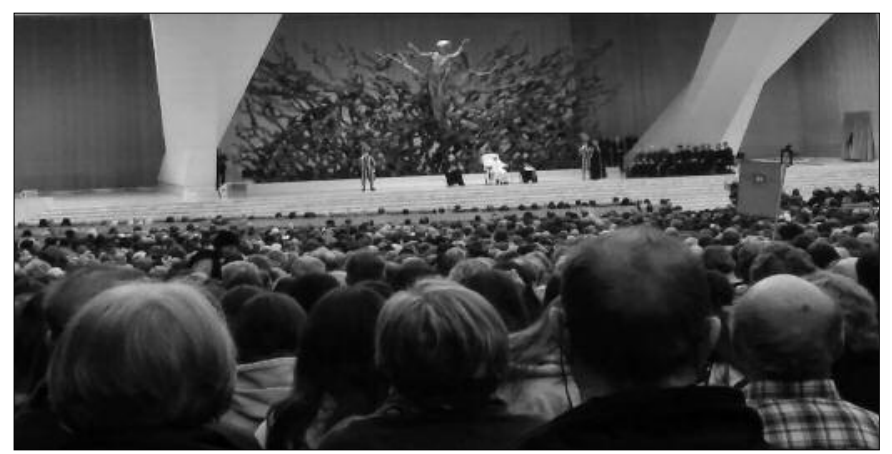

Аудиенциия с Папа Францฺиск, 28.02.2018

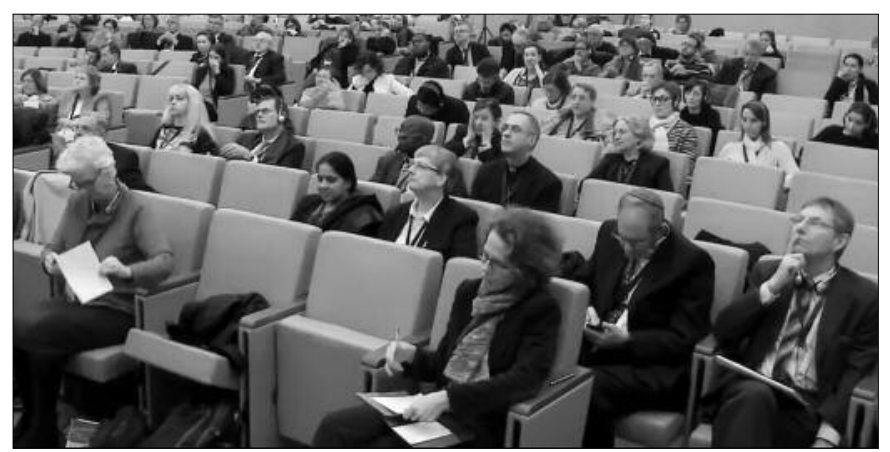

Изльчване на живо секции:

Програмата беше организирана в няколко тематични

Ценност на палиативните грижи. Докладчици от Андерсон раков център към Университета в Тексас, Университета в Глазгоу, С3О, Springer Medizin, Aerzte ZeitungГермания обхванаха темите за подобряването на симптомите на раковите заболявания в резултат на палиативните грижи, подобряването на обществото като цяло, ефекта от палиативните грижи върху здравето и медицината.

Палиативни грижни навсякъде. Докладчици от УНиверситетския колеж в Дъблин, Държавния университет Вирджиния, Асоциацията по палиативни грижи в Латинска Америка, Католическия университет в Корея, Африканската Асоциация по палиативни грижи, Националния център за онкологична грижа и изследвания в Доха, Катар, Католическата здравна асоциация в Индия и Международната асоциация за хосписни и палиативни грижи говориха за интегрирането на палиативните грижи в Европа, изследванията в областта на палиативните грижи в Северна Америка, развитието им в Южна Америка, опитът с духовната подкрепа в рамките на палиативните грижи в Азия, културалните фак- тори, повлияващи палиативните грижи в арабските страни, включването на общността в оказването на палиативни грижи в Индия, работата на международните институции в подкрепата на палиативните грижи като човешко право.

Палиативни грижи за всеки. Докладчици от Израел, Швейцария, САЩ, Белгия и Италия представиха различните религиозни перспективи на палиативните грижи - християнство, ислям, хиндуизъм, юдаизъм, както и интегрирането на духовната подкрепа в палиативните грижи.

Политики и финансови измерения. Заключителна сесия, в която докладчици от Ирландия, Индия, САЩ и Германия говориха за предизвикателствата и добрите практики във финансирането на палиативните грижи.

Със съжаление трябва да отбележа, че страни с много по-скромен БВП вече са ни изпреварили в редица аспекти на палиативните грижи. Изключително впечатление прави обществената ангажираност за развитието на палиативните грижи и разгръщането на духовния им елемент, които се наблюдават в страни с различни доминиращи религии, но найвече сред католическите страни. В този план огромно впечатление с обединяването на общността около споделени морални ценности ми направи аудиенцията с Папа Франциск, в която имах шанса да участвам на 28.02.2018. След срещата ми с Далай Лама през 2014 г., това беше втора уникална въ3можност да видя и чуя на живо един от признатите духовни водачи на съвременното ни общество.

Личното ми участие в програмата на конгреса беше в постерната сесия с постер на тема ,METAP подход за клинично етично консултиране в случай на съобщаване на истината в условията на палиативни грижи в България". Материальт представя най-нови аспекти на научните ми интереси в областта на клиничното етично консултиране и е разработен съвместно с д-р Николай Йорданов и Мария Костова от КОЦ, Враца. Конкретният казус, наложил етично консултиране, е на пациентка с метастатичен карцином, която не е информирана за диагнозата и прогнозата си поради разногласие между близките иे и лекуващият екип. Представената методология, която е създадена в Университетската болница в Базел и е утвърдена в Европа, предизвика интерес и обстойни дискусии с колегите от Университета в Хюстън и Департамента по етика на здравните грижи в Бостън, САЩ.

В заключение искам да подчертая необходимостта от извеждане на развитието на палиативните грижи у нас сред приоритетните области на здравната ни политика. Изследвам проблема още от 2001 г., но за изминалото десетилетие единичните усилия на качествени професионалисти в областта на палиативните грижи не доведоха до категорична промяна в техния статут. Силно ограничени са възможностите на здравноосигурените пациенти да се възползват от палиативни грижи в рамките на съществуващата клиничната пътека. България е в парадоксалната ситуация да е сред най-застарелите държави в Европа без да извежда развитието на палиативните грижи сред националните си приоритети и на практика те са оставени изцяло на частно и проектно финансиране. Отделен въпрос е и хармоничното развитие на отделните елементи на палиативните грижи, където в нашите условия страда духовната подкрепа и грижата за близките на терминално болните. Палиативните грижи не са печеливша област на медицинската и обществената грижа, но те показват зрелостта на едно общество да се грижи за най-уязвимите си групи, за своите майки и бащи.

Проф. Силвия Александрова-Янкуловска, Факултет „Обществено здраве“, МУ -Плевен

$$
* *
$$

